\title{
Smartphone Image based Agricultural Product Quality and Harvest Amount Prediction Method
}

\author{
Fertilizer Control through Quality Prediction by using \\ Smartphone Images of Agricultural Products
}

\author{
Kohei Arai $^{1}$ \\ Faculty of Science and Engineering \\ Saga University, Saga City, Japan
}

\author{
Osamu Shigetomi ${ }^{2}$, Yuko Miura ${ }^{3}$, Satoshi Yatsuda ${ }^{4}$ \\ Saga Prefectural Agricultural Research Institute \\ Saga Prefecture, Saga City, Japan
}

\begin{abstract}
A method for agricultural product quality and harvest amount prediction by using smartphone camera image is proposed. It is desired to predict agricultural product quality and harvest amount as soon as possible after the sowing. In order for that, satellite imagery data, UAV camera based images, ground based camera images are used and tried These methods do cost significantly and these do not work so well due to some reasons, in particular, most of farmers cannot use these properly. The proposed method uses just smartphone camera acquired images. Therefore, it is totally easy to use. If the results of prediction of product quality and harvest amount are not satisfied, then farmers have to add some additional fertilizer at the appropriate time. The experimental results with soy plantations show some possibility of the proposed method.
\end{abstract}

Keywords-Smartphone camera image; agricultural product quality and harvest prediction; fertilizer control; soy plantation

\section{INTRODUCTION}

Isoflavones are most specific feature of soy. Therefore, soy farmers intend to find species which is isoflavone rich species and also intend to control water supply, fertilizer etc. for improving soy quality and harvest amount. Because isoflavones are ubiquitous in the germ part. Therefore, it is not so easy to estimate the isoflavone content in the planted soy.

Nitrogen content estimation of rice crop based on Near Infrared (NIR) reflectance using artificial neural network (ANN) is conducted [1]. Rice crop field monitoring system with radio controlled helicopter based near infrared cameras through nitrogen content estimation and its distribution monitoring is proposed [2]. Rice crop quality evaluation method through regressive analysis between nitrogen content and near infrared reflectance of rice leaves measured from near field radio controlled helicopter is also proposed and well reported [3]. Furthermore, a relation between rice crop quality (protein content) and fertilizer amount as well as rice stump density derived from helicopter data is well reported [4]. Then estimation of rice crop quality and harvest amount from helicopter mounted NIR camera data and remote sensing satellite data is proposed [5].

Effect of stump density, fertilizer on rice crop quality and harvest amount in 2015 investigated with drone mounted NIR camera data is also confirmed [6]. Method for NIR reflectance estimation with visible camera data based on regression for
NDVI estimation and its application for insect damage detection of rice paddy fields is discussed [6]. Artificial Intelligence: AI baaed fertilizer control for improvement of rice quality and harvest amount is proposed and well validated the proposed method with rice paddy field data. [7]. Method for NIR reflectance estimation with visible camera data based on regression for NDVI estimation and its application for insect damage detection of rice paddy fields is proposed [8]. Also, artificial intelligence baaed fertilizer control for improvement of rice quality and harvest amount is proposed [9].

It is not always possible to acquire the remote sensing satellite data due to the limitation of revisit cycle of the satellite orbit. Neither, it is not possible to acquire UAV camera images due to the limitation of wind speed, weather condition, and so on. On the other hand, ground based cameras have problems on sun illumination condition difference, shading and shadowing, etc. Moreover, these methods do cost very much.

Meanwhile, the proposed requires only smartphone camera derived images. Therefore, it is easy to use and does not require much cost. Only thing the farmers have to do is just acquire images of the soy plantations (example of agricultural products) and send these to the image collection center. After the farmers send their acquired images, the image collection center analyzed data, and predict their product quality and harvest amount and send the predicted result with some appropriate instructions for fertilizer control (fertilizer amount and timing) to the farmers.

In the following section, the proposed prediction method and system will described followed by experimental set-up together with experimental results. After that, concluding remarks and some discussions will be described.

\section{PROPOSED METHOD}

\section{A. System Configuration}

Fig. 1 shows the proposed system configuration and the procedure. Following is the detailed procedure:

1) Farmer sends smartphone images to the image collection center.

- Register the system

- Report conditions 


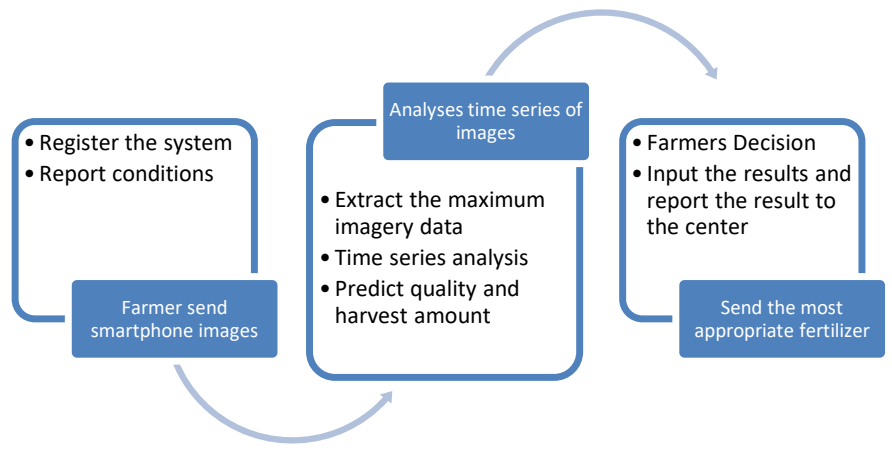

Fig. 1. Proposed System Configuration and the Procedure.

2) Analyses time series of the acquired smartphone images

- Extract the maximum imagery data

- Time series analysis

- Predict quality and harvest amount

3) Send the most appropriate fertilizer control

- Farmers Decision

- Input the results and report the result to the center

\section{B. Method for Prediction of Harvested Soy Products and Harvest Amount}

In this regard, the prediction methods of product quality and harvest amount are key issues here. These methods are based on the experimental results which are described in the next section. These are basically based on a correlation analysis, and a linear regressive analysis. In the year 2018, some experiments were conducted at the soy farm areas which are situated at the Saga prefectural research institute. The experimental data encourages us to use the correlations between the maximum image pixel value and isoflavone content and protein content in the harvested soy beans as well as harvest amount. Therefore, the results of the regressive analysis are reliable.

Essentially, the proposed methods for soy bean quality evaluation and harvest amount prediction are based on regressive analysis by using smartphone acquired camera imagery data.

\section{EXPERIMENTS}

\section{A. Experiment Procedure}

Sowing time, fertilizer time and flowing time of the two types of soy (Sakukei 207: New specie, and the traditional Fukuyutaka) are shown in Table I. Smartphone camera data are acquired on the following dates:

July 26, August 17, 22, 27, September 11, 25 in 2018
TABLE. I. THE TIME FOR SOWING, FerTILIZER, FLOwING OF THE Two SPECIES OF SOY

\begin{tabular}{|l|l|l|l|l|}
\hline & Sakukei207 & Sakukei207 & Sakukei207 & Fukuyutaka \\
\hline Sowing & June 4 & June 27 & July 12 & July 12 \\
\hline Original fertilizer & July 24 & Aug.14 & Aug.24 & Aug.27 \\
\hline Second & Aug.6 & Aug.28 & Sep.6 & Sep.10 \\
\hline Third & Aug.20 & Sep.11 & Sep.21 & Sep24 \\
\hline Flowing & July 23 & Aug.12 & Aug.22 & Aug.25 \\
\hline
\end{tabular}

In conjunction with camera data acquisition, spectral reflectance measurements and sample collection is conducted. The collected samples are used for the truth data of isoflavone, phospholipid, nitrogen content, water content of the harvested soy beans. The method for the chemical truth variables are as follows:

1) High performance liquid chromatography: The total amount of daidzin, glycitin, genistin and their respective aglycones, acetyls and malonyls, acetyls and malonyls were calculated as daidzin, glycitin or genistin and corrected with molecular weight.

2) Phospholipids as stearo, oleo and lecithin: It was converted by a factor of 25.4 from phosphorus determined by the colorimetric method.

\section{B. Intensive Study Area}

Intensive study area is situated at the Saga Prefectural Agricultural Research Institute as shown in Fig. 2. There are four lines of moth. From the right, Sakukei207 (6/4), Sakukei207 (6/27), Sakukei207 (7/12) and Fukuyutaka (7/12) are aligned in the soy farm area of test site.

There are two types of cameras, visible camera and NIR filter attached camera. As shown in the previous paper, it is possible to replace NIR filtered camera with visible camera. Therefore, visible cameras are fine to collect the photos of the soy plantations for estimation of product quality and harvest amount.

\section{Acquired Smartphone Camera Images}

Examples of the acquired smartphone camera images are shown in Fig. 3. Each figure includes green color of histogram as well as mean, standard deviation, minimum and maximum pixel values of the rectangle areas. These statistics are shown in Table II.

TABLE. II. MEAn, Standard DEVIATION, Minimum AND MaXimum PIXEL VALUES OF THE RECTANGLE AREAS

\begin{tabular}{|l|l|l|l|l|}
\hline & June 4 S & June 27 S & July 12 S & July 12 F \\
\hline Mean & 125.48 & 135.1 & 106.11 & 110.85 \\
\hline Std. & 19.25 & 20.35 & 35.16 & 38.38 \\
\hline Min. & 60 & 58 & 38 & 22 \\
\hline Max. & 218 & 225 & 230 & 223 \\
\hline
\end{tabular}




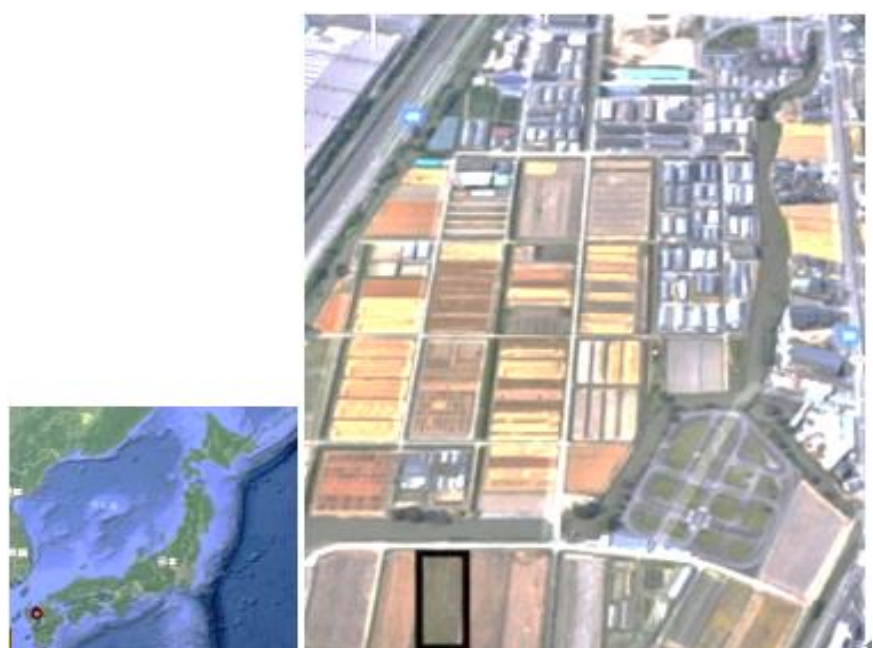

(a) Test Site on Map (Test Site is Situated at the Red Circle) (b) SPARI

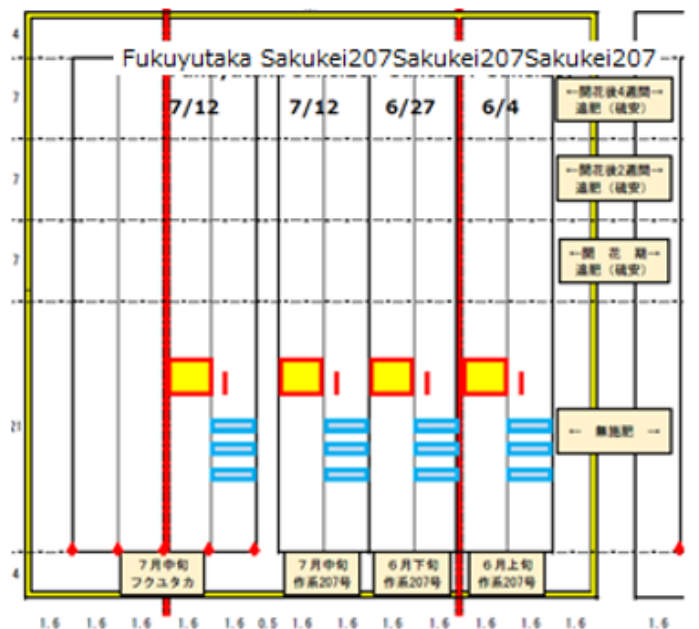

(c) Test Site on 3D Aerial Photo Image of Google Map.

Fig. 2. Test Site.

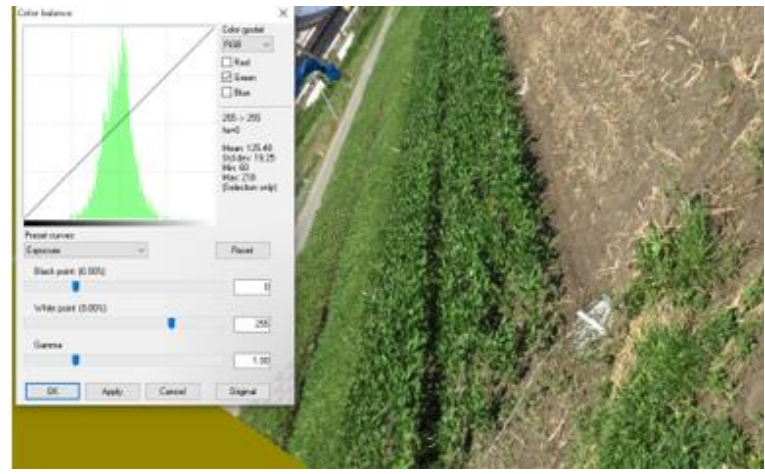

(a)Sakukei207(6/4)

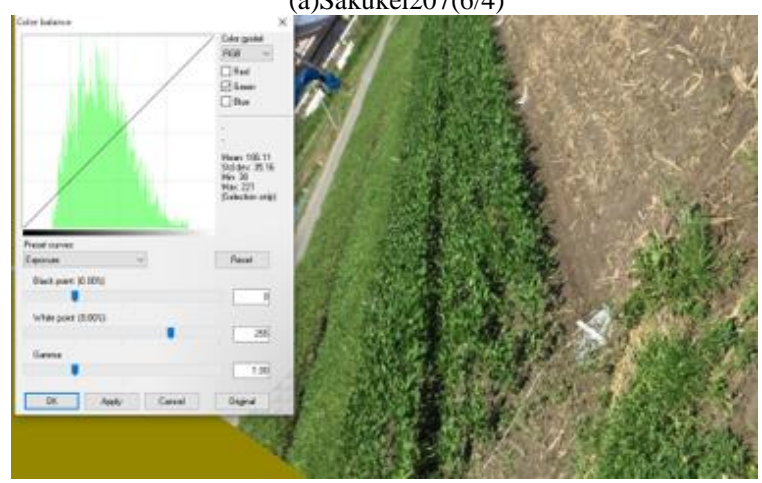

(c) Sakukei207(7/12)

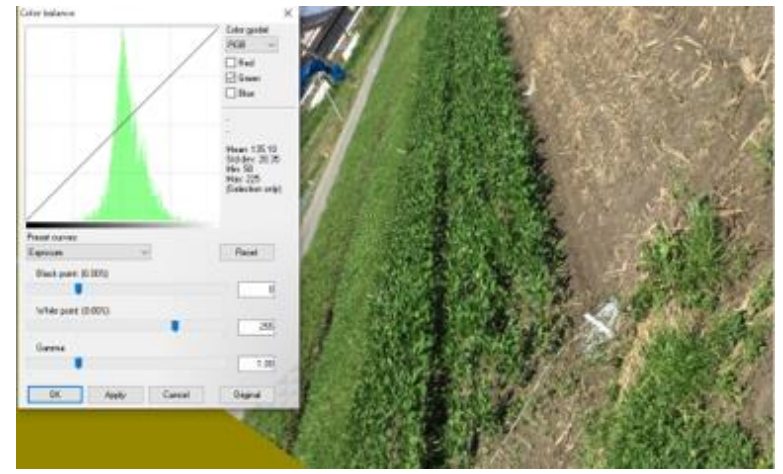

(b)Sakukei207(6/27)

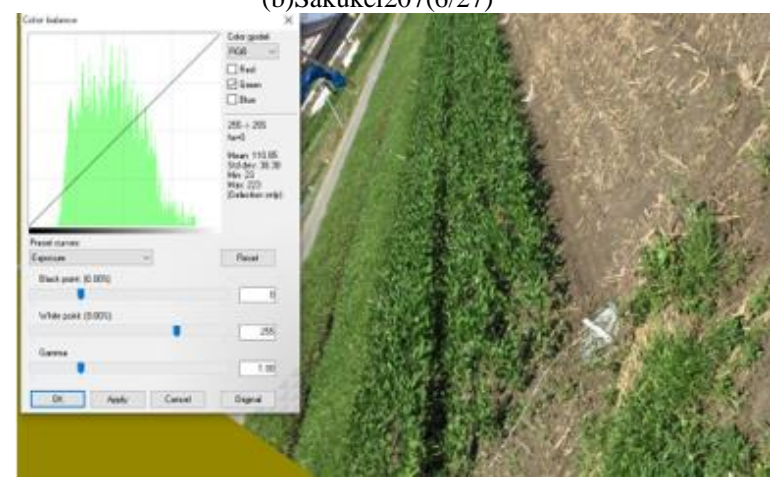

(d) Fukuyutaka(7/12)

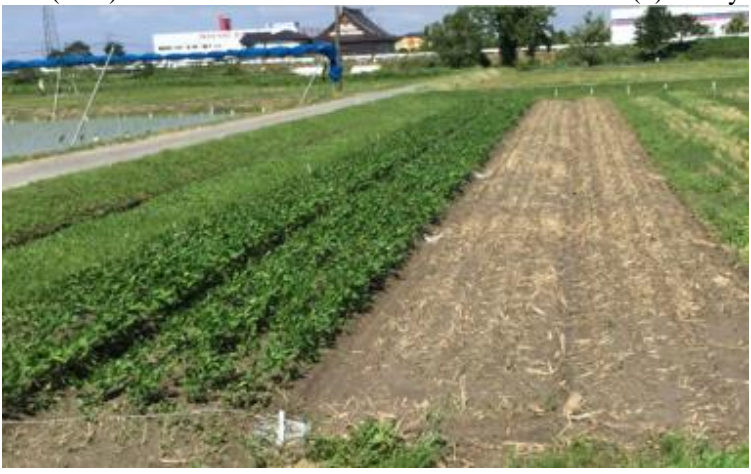

(e) Original Image

Fig. 3. Example of the Acquired Soy Plantation Images with Smartphone. 
Where, "S" stands for Sakukei207 while "F" stands for Fukuyutaka, respectively.

\section{Acquired Spectral Reflectance of Soy Plantations}

Meanwhile, spectral reflectance of the soy plantations is measured. Therefore, NIR image (at around $800 \mathrm{~nm}$ ) of image can be estimated with visible colored smartphone camera images. Example of the measured spectral reflectance is shown in Fig. 4.

If just reflectance at $800 \mathrm{~nm}$ of the soy plantation horizontally is taken into account, then Fig. 5 of horizontal profile of the measured reflectance of soy plantation can be shown.

These reflectance are measured on September 252018.

\section{E. Measured Truth Data}

The measured truth data are as follows:

Soy isoflavone, Phospholipid, Nitrogen content, water content and protein content in the harvested soy beans and harvest amount. Firstly, the following correlation analysis is conducted with the measured reflectance of the soy plantation and protein content, water content, as well as harvest amount.

F. Correlation Analysis and Linear Regression Between Smartphone Camera Derived Reflectance at 800 $\mathrm{nm}$ and the Truth Data

The relation between the measured reflectance of soy plantation at $800 \mathrm{~nm}$ and water content, protein content of the harvested soy beans and harvest amount is shown in Fig. 6. From the figure, it is found that there is not so small correlation between the measured reflectance and protein content and also harvest amount. Therefore, it is possible to predict these two parameters (harvest amount and protein content) from reflectance measurement with not only spectral-radiometer, but also smartphone camera. Even if the spectral coverage of the smartphone camera rages from blue to red, it is still possible to estimate the reflectance at $800 \mathrm{~nm}$ with visible smartphone camera if a calibration between visible camera and spectralradiometer is conducted. On the other hand, there is no such correlation between the measured reflectance at $800 \mathrm{~nm}$ and water content in the harvested soy beans.

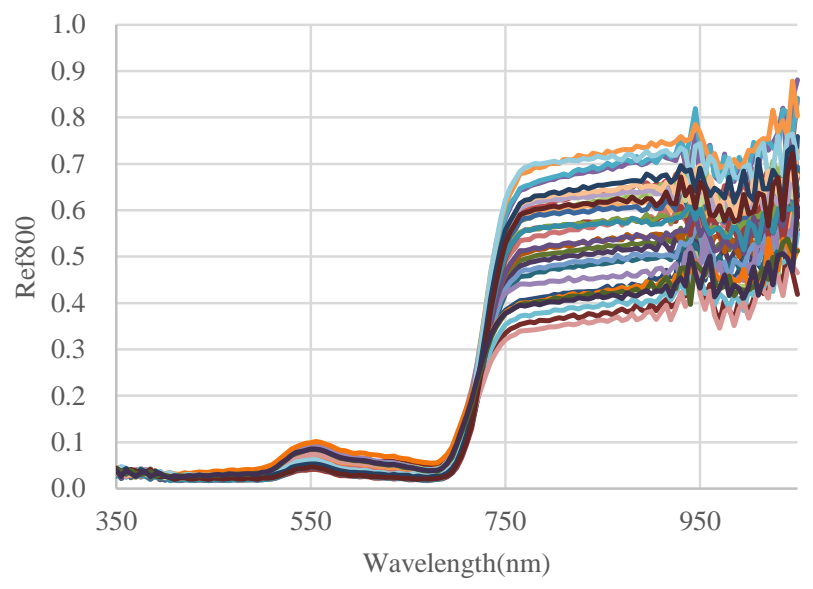

Fig. 4. Example of the Measured Spectral Reflectance of the Soy Plantations.

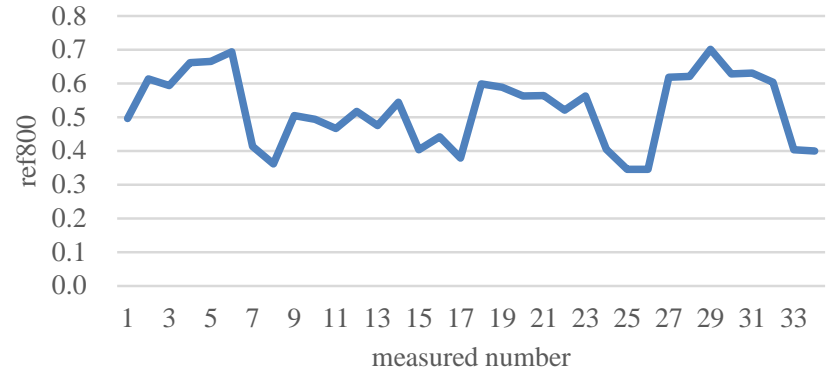

Fig. 5. Horizontal Profile of the Measured Reflectance of Soy Plantation.

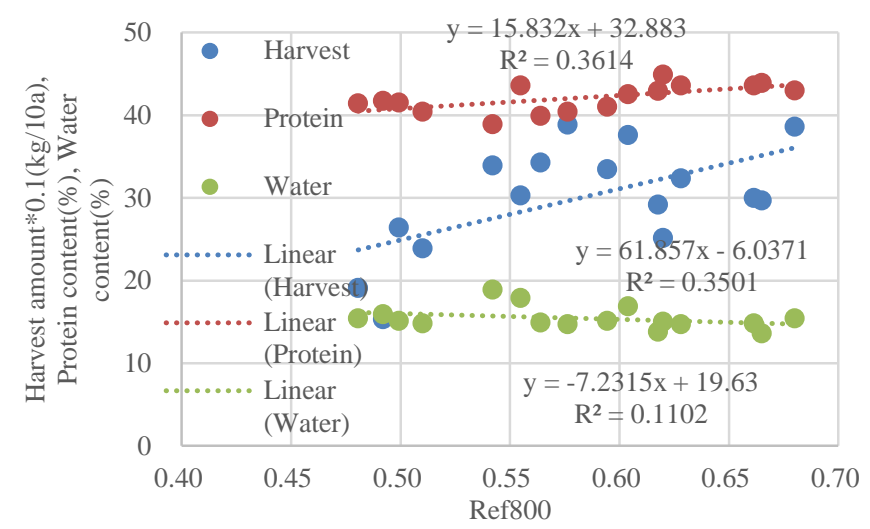

Fig. 6. The Relation between the Measured Reflectance of Soy Plantation at $800 \mathrm{~nm}$ and Water Content, Protein Content of the Harvested Soy Beans and Harvest Amount.

The regressive equations and $\mathrm{R}$ square values for protein content in soy beans, harvest amount and water content in soy beans are as follows:

$\mathrm{p}=15.832 \mathrm{x}+32.883$

$\mathrm{R}^{2}=0.3614$

$\mathrm{h}=61.857 \mathrm{x}-6.0371$

$\mathrm{R}^{2}=0.3501$

$\mathrm{w}=-7.2315 \mathrm{x}+19.63$

$\mathrm{R}^{2}=0.1102$

Therefore, it can be said that protein content in soy beans and harvest amount can be predicted with the measured reflectance of the soy leaves at $800 \mathrm{~nm}$ in some sense (around 0.6 of correlation coefficient between both). Also, it is not possible to estimate water content in soy beans with the measured reflectance of the soy leaves at $800 \mathrm{~nm}$.

It is also found that there is strong correlation between maximum pixel value and soy isoflavone and Phospholipids nevertheless the correlation between reflectance at $800 \mathrm{~nm}$ and soy isoflavone and Phospholipids is week. The correlation between soy isoflavone is much stronger $(0.821)$ than that between Phospholipids (0.309) as shown in Table III.

Because the pixel values in the smartphone camera image are variated due to the angle of the soy plant leaves and camera looking angle are so different, the maximum pixel value is much more appropriate for the correlation analysis. 


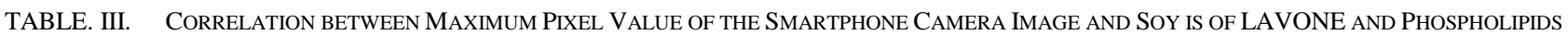

\begin{tabular}{|l|l|l|l|l|l|l|}
\hline & Soy isoflavone (g/100g) & Phospholipid (g/100g) & $\mathrm{y}=(\mathrm{x}-\mathrm{m})^{\wedge} 2 / \mathrm{s}^{\wedge} 2$ & $1 / \mathrm{y}$ & $\mathrm{R}_{800}$ \\
\hline Sakukei207 (June 4)with & 0.34 & 1.6 & 0.104 & 9.592 & 0.6 & 218 \\
\hline Sakukei207 (June 27) & 0.34 & 1.64 & 0.104 & 9.592 & 225 \\
\hline Sakukei207 (July 12) & 0.43 & 1.63 & 3.072 & 0.326 & 0.48 \\
\hline Fukuyutaka (July 12) & 0.32 & 1.61 & 0.615 & 1.626 & 230 & 223 \\
\hline Sakukei207 (June 4)without & 0.34 & 1.64 & 0.104 & 9.592 & 0.58 \\
\hline Correlation R800 & 0.313 & -0.162 & 0.454 & -0.543 & & \\
\hline Correlation max.pixel & 0.732 & 0.309 & 0.821 & -0.710 & \\
\hline
\end{tabular}

As the result, it is found that it is possible to predict soy isoflavone content, protein content and harvest amount with the acquired smartphone camera image in the early stage of the soy plantation. In this case the smartphone camera image which is taken on July 262018 is used. It means that soy isoflavone content, protein content as well as harvest amount can be predicted 13 days after the sowing. Therefore, fertilizer control can be done properly and appropriately.

On the other hand, Table IV shows the result from the correlation analysis between the maximum pixel value and nitrogen content in the moth, seed and stem as well as the measured reflectance of soy plantation at $800 \mathrm{~nm}$ and nitrogen content in the moth, seed and stem. As shown in Table IV, there is strong correlation between the maximum pixel value and nitrogen content in the moth as well as the maximum pixel value and nitrogen content in the seed.

However, it is found that the correlation between the maximum pixel value and nitrogen content in the stem is very week. Furthermore, the correlations with the maximum pixel values are much stronger than the measured reflectance at $800 \mathrm{~nm}$. Therefore, it is concluded that correlation analysis would be better to be conducted with the maximum pixel value of the acquired smartphone camera images rather than the measured reflectance at $800 \mathrm{~nm}$.

Also, it is found that it is possible to predict nitrogen content in soy plant moth and seed by taking smartphone camera image of the soy plantation in concern.

TABLE. IV. RESULT FROM THE CORRELATION ANALYSIS BETWEEN THE MaXimum Pixel Value and Nitrogen Content in THE Moth, SEED AND

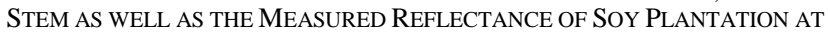
800NM AND NitROGEN CONTENT IN THE MOTH, SEED AND STEM

\begin{tabular}{|l|l|l|l|l|l|}
\hline & Moth & Seed & Stem & Max. & R800 \\
\hline $\begin{array}{l}\text { Sakukei207(June } \\
\text { 4)with }\end{array}$ & 1.19 & 6.92 & 0.72 & 218 & 0.6 \\
\hline Sakukei207(June 27) & 0.97 & 6.44 & 0.73 & 225 & 0.48 \\
\hline Sakukei207(July 12) & 0.93 & 6.63 & 0.69 & 230 & 0.58 \\
\hline Fukuyutaka(July 12) & 0.76 & 6.8 & 0.51 & 223 & 0.66 \\
\hline $\begin{array}{l}\text { Sakukei207(June } \\
\text { 4)without }\end{array}$ & 1.25 & 6.59 & 0.8 & 218 & 0.68 \\
\hline $\begin{array}{l}\text { Correlation between } \\
\text { R800 }\end{array}$ & 0.02357 & 0.396693 & -0.18483 & & \\
\hline $\begin{array}{l}\text { Correlation between } \\
\text { max.pixel }\end{array}$ & -0.67314 & -0.41736 & -0.28206 & & \\
\hline
\end{tabular}

A method for agricultural product quality and harvest amount prediction by using smartphone camera image is proposed. It is desired to predict agricultural product quality and harvest amount as soon as possible after the sowing. In order for that, satellite imagery data, UAV camera based images, ground based camera images are used and tried These methods do cost significantly and these do not work so well due to some reasons, in particular, most of farmers cannot use these properly. The proposed method uses just smartphone camera acquired images. Therefore, it is totally easy to use. If the results of prediction of product quality and harvest amount are not satisfied, then farmers have to add some additional fertilizer at the appropriate time. The experimental results with soy plantations show some possibility of the proposed method.

It is also found that there is strong correlation between maximum pixel value and soy isoflavone and Phospholipids nevertheless the correlation between reflectance at $800 \mathrm{~nm}$ and soy isoflavone and Phospholipids is week. The correlation between soy isoflavone is much stronger (0.821) than that between Phospholipids (0.309).

There is strong correlation between the maximum pixel value and nitrogen content in the moth as well as the maximum pixel value and nitrogen content in the seed. However, it is found that the correlation between the maximum pixel value and nitrogen content in the stem is very week. Furthermore, the correlations with the maximum pixel values are much stronger than the measured reflectance at $800 \mathrm{~nm}$. Therefore, it is concluded that correlation analysis would be better to be conducted with the maximum pixel value of the acquired smartphone camera images rather than the measured reflectance at $800 \mathrm{~nm}$. Also, it is found that it is possible to predict nitrogen content in soy plant moth and seed by taking smartphone camera image of the soy plantation in concern.

\section{FUTURE RESEARCH WORKS}

Further experimental studies are required for the validation of the proposed method. Also, applicability of the proposed method has to be confirmed through further experiments.

\section{ACKNOWLEDGMENT}

The authors would like to thank to Professor Dr. Hiroshi Okumura and Professor Dr. Osamu Fukuda for their valuable discussions. 


\section{REFERENCES}

[1] Setia Damawan Afandi, Yeni Herdiyeni, Lilik B. Prasetyo, Wahyudi Hashi, Kohei Arai, Hiroshi Okumura, Nitrogen Content Estimation of rice Crop Basedon Near Infrared (NIR) reflectance Using Artificial Neural Network (ANN), Procedia Environmental Sciences, Elsevier, 33, 63-69, 2016.

[2] Kohei Arai, Osamu Shigetomi, Yuko Miura, Hideaki Munemoto, Rice crop field monitoring system with radio controlled helicopter based near infrared cameras through nitrogen content estimation and its distribution monitoring, International Journal of Advanced Research in Artificial Intelligence, 2, 3, 26-37, 2013.

[3] Kohei Arai, Rice crop quality evaluation method through regressive analysis between nitrogen content and near infrared reflectance of rice leaves measured from near field radio controlled helicopter, International Journal of Advanced Research in Artificial Intelligence, 2, 5, 1-6, 2013.

[4] Kohei Arai, Masanori Sakashita, Osamu Shigetomi, Yuko Miura, Estimation of protein content in rice crop and nitrogen content in rice leaves through regressive analysis with NDVI derived from camera mounted radio-control helicopter, International Journal of Advanced Research in Artificial Intelligence, 3, 3, 7-14, 2014.

[5] Kohei Arai, Masanori Sakashita, Osamu Shigetomi, Yuko Miura, Relation between rice crop quality (protein content) and fertilizer amount as well as rice stump density derived from helicopter data, International Journal of Advanced Research on Artificial Intelligence, 4, 7, 29-34, 2015.

[6] Kohei Arai, Masanori Sakashita, Osamu Shigetomi, Yuko Miura, Estimation of Rice Crop Quality and Harvest Amount from Helicopter Mounted NIR Camera Data and Remote Sensing Satellite Data, International Journal of Advanced Research on Artificial Intelligence, 4, 10, 16-22, 2015.

[7] Kohei Arai, Gondoh, Miura, Shigetomi, Effect of Stump density, Fertilizer on Rice Crop Quality and Harvest Amount in 2015
Investigated with Drone mounted NIR Camera Data, International journal of Engineering Science and research Technology, 2, 2, 1-7, 2016.

[8] Kohei Arai, Kenji Gondoh, Osamu Shigetomi, Yuko Miura, Method for NIR Reflectance Estimation with Visible Camera Data Bsed on Regression for NDVI Estimation and Its Application for Insect Damage Detection of Rice Paddy Fields, International Journal of Advanced Research on Artificial Intelligence, 5, 11, 17-22, 2016.

[9] Kohei Arai, Osamu Shigetomi, Yuko Miura, Artificial Intelligence Baed Fertilizer Control for Improvement of Rice Qualityt and Harvest Amount, International Journal of Advanced Computer Science and Applications: IJACSA, 9, 10, 61-67, 2018.

\section{AUTHOR's PROFILE}

Kohei Arai, He received BS, MS and PhD degrees in 1972, 1974 and 1982, respectively. He was with The Institute for Industrial Science and Technology of the University of Tokyo from April 1974 to December 1978 also was with National Space Development Agency of Japan from January, 1979 to March, 1990. During from 1985 to 1987, he was with Canada Centre for Remote Sensing as a Post Doctoral Fellow of National Science and Engineering Research Council of Canada. He moved to Saga University as a Professor in Department of Information Science on April 1990. He was a councilor for the Aeronautics and Space related to the Technology Committee of the Ministry of Science and Technology during from 1998 to 2000. He was a councilor of Saga University for 2002 and 2003. He also was an executive councilor for the Remote Sensing Society of Japan for 2003 to 2005 . He is an Adjunct Professor of University of Arizona, USA since 1998. He also is Vice Chairman of the Science Commission "A" of ICSU/COSPAR since 2008 then he is now award committee member of ICSU/COSPAR. He wrote 37 books and published 570 journal papers. He received 30 of awards including ICSU/COSPAR Vikram Sarabhai Medal in 2016, and Science award of Ministry of Mister of Education of Japan in 2015. He is now Editor-in-Chief of IJACSA and IJISA. http://teagis.ip.is.saga-u.ac.jp/index.html. 